\title{
The forelimb of $\dagger$ Cyonasua sp. (Procyonidae, Carnivora): ecomorphological interpretation in the context of
} carnivorans

\author{
J. Tarquini ${ }^{1,2^{*}}$, N. Toledo ${ }^{1,2}$, C. C. Morgan ${ }^{1,3}$ and L. H. Soibelzon ${ }^{1,2}$
}

${ }^{1}$ Consejo Nacional de Investigaciones Científicas y Técnicas (CONICET), Argentina.

${ }^{2}$ División Paleontología Vertebrados, Facultad de Ciencias Naturales y Museo, Universidad Nacional de La Plata, Paseo del Bosque s/n, B1900FWA, La Plata, Argentina.

${ }^{3}$ División Zoología de Vertebrados, Sección Mastozoología, Facultad de Ciencias Naturales y Museo, Universidad Nacional de La Plata, Paseo del Bosque s/n, B1900FWA, La Plata, Argentina.

*Corresponding author: julitarquini@gmail.com

\begin{abstract}
The procyonid †Cyonasua is endemic to South America and recorded from the Late Miocene to the Early Pleistocene. This paper studies the forelimb of $\uparrow$ Cyonasua sp. (late Pliocene of Miramar, Argentina), using an ecomorphological approach to infer morphological adaptations linked to substrate preference and locomotory mode, as well as to grasping and digging ability. Twenty linear measurements of forelimb and pectoral girdle were taken from $\dagger$ Cyonasua sp. and a sample of 87 specimens of extant carnivoran families (Procyonidae, Mustelidae, Ursidae, Viverridae, Canidae and Felidae). Raw values were transformed to minimise the effect of size. Morphological variation was explored by principal component analysis (PCA); substrate preference and locomotory mode were further analysed by multivariate analysis of variance (MAV) and discriminant analysis (DA); grasping and digging ability were analysed by DA. In the PCA morphospace, $†$ Cyonasua sp. occupied a unique position, close to extant procyonids. DA classified it as non-specialised digger with poor grasping ability. The results lead to the interpretation of $\dagger$ Cyonasua sp. as having a moderately stabilised elbow joint with poor pronation-supination, although some climbing skills cannot be ruled out. Thus, †Cyonasua sp. could have had generalised habits, in agreement with reconstructed palaeoenvironmental conditions.
\end{abstract}

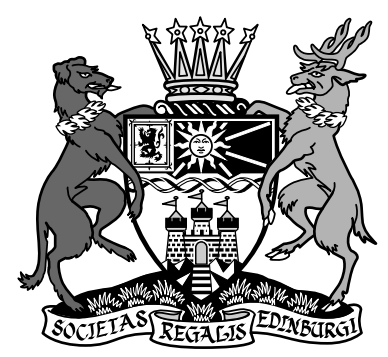

KEY WORDS: digging, ecomorphology, grasping, locomotory mode, procyonids, substrate preference

The family Procyonidae was the first group of carnivorans to reach South America after the marine barrier separating North and South America disappeared ca. 4-2.5 Ma (see Woodburne et al. 2006; Soibelzon \& Prevosti 2007, 2012; O'Dea et al. 2016). The presence of this family in South America is recorded from the Late Miocene to recent times; with six extinct genera described, but only two considered as valid at the present time: $†$ Cyonasua Ameghino, 1885, recorded from the Late Miocene to Early Pleistocene; and $\uparrow$ Chapalmalania Ameghino, 1908, during the Pliocene. †Cyonasua is endemic to South America and comprises ten formally named species: $\dagger$ C. argentina Ameghino, 1885; $\uparrow$ C. brevirrostris (Moreno \& Mercerat 1891); $\dagger$ C. longirostris (Rovereto 1914); $\dagger$ C. pascuali Linares, 1981; $\dagger$ C. groeberi Kraglievich \& Reig, 1954; $\dagger$ C. lutaria (Cabrera 1936); $\dagger$ C. clausa (Ameghino 1904); $\dagger$ C. robusta; $\dagger C$. argentinus (Burmeister 1891); and $\dagger$ C. meranii (Ameghino \& Kraglievich 1925) (Soibelzon 2011). Despite the large number of $\dagger$ Cyonasua species, specimens are relatively scarce and most remain unpublished (Soibelzon 2011).

It is noteworthy that the fossil record of Procyonidae in South America has a gap of $0.9 \mathrm{Ma}$. between the early Pleistocene, when $\uparrow$ Cyonasua is recorded for the last time, and the latest Pleistocene, when Procyon and Nasua are first recorded (Soibelzon 2011). Extant South American procyonids represent a second invasion from North or Central America occurring during the latest Pleistocene-Holocene, and are not directly related to $†$ Cyonasua or $†$ Chapalmalania (Soibelzon 2011; Forasiepi et al. 2014).

Extant procyonids are represented by six genera (Bassaricyon Allen, 1876; Bassariscus Coues, 1887; Nasuella Hollister, 1915; Potos Geoffroy Saint-Hilaire \& Cuvier, 1795; Procyon Storr, 1780 and Nasua Storr, 1780), ranging from 1-10 kg (Wilson \& Mittermeier 2009). They occupy diverse habitats, except deserts (Grzimek et al. 2004), and display a variety of locomotor habits and substrate preferences (McClearn 1992; Nowak 2005; Fulton \& Strobeck 2007; Wilson \& Mittermeier 2009). All are able to climb; Procyon (P. cancrivorus, $8.5 \mathrm{~kg}$, Canevari \& Vaccaro 2007 and $P$. lotor, $6.4 \mathrm{~kg}$, Jones et al. 2009), Nasua (N. nasua, 4.3 kg, Gompper \& Decker 1998 and $N$. narica Gompper, 1995) and Nasuella (1.34 kg, Jones et al. 2009) spend most of their inactive time on trees but forage on the ground (McClearn 1992); Bassariscus (1.01 kg, Jones et al. 2009) are specialised for climbing to find food and homes, but also move along cliffs and rocky outcrops (Wilson \& Mittermeier 2009); whereas Potos (3 kg, Grzimek et al. 2004) and Bassaricyon (1.4 kg, Helguen et al. 2013) are exclusively arboreal (Wilson \& Mittermeier 2009). Procyon uses its forefeet to locate and handle prey and Nasua frequently digs holes to capture subterranean prey (McClearn 1992; Gompper \& Decker 1998). Because of this ecological diversity, procyonids represent an interesting model for morphofunctional analysis of their postcranial skeleton. In particular, the forelimbs which, as in 
other carnivores, participate not only in locomotion (including swimming and/or climbing), but also in other activities such as digging and foraging, including prey capture and manipulation (Iwaniuk et al. 1999; Andersson 2004; Nowak 2005; Fabre et al. 2013; Martín-Serra et al. 2014). Thus, forelimbs are potentially significant to link morphological features to ecological traits.

Furthermore, the patterns observed in an ecologically diverse sample of living Carnivora can subsequently be applied to draw inferences about the substrate preferences, locomotory mode and potential capacities of extinct taxa, such as $\uparrow$ Cyonasua. These inferences could be drawn from morphometric analyses of the relationship between shape and function (e.g., Van Valkenburgh 1987; Vizcaíno \& Milne 2002; Andersson 2003, 2004; Elissamburu \& Vizcaíno 2004; Toledo et al. 2012; Samuels et al. 2013). However, there have been no extensive studies of the ecomorphological diversity of the procyonid forelimb, either in living or extinct members of the family (Andersson 2003; Tarquini et al. 2012; Fabre et al. 2013, 2014, 2015; MartínSerra et al. 2014; Junior et al. 2015) and, thus, potentially informative features have not been explored.

The goal of this work is to perform a morphometric analysis of the forelimb morphology of the extinct procyonid $\uparrow$ Cyonasua for the first time in the context of a wide sample of living carnivorans. Preliminary body size estimations, based on allometric regression of postcranial linear dimensions (Tarquini et al. 2015), have yielded values around $19 \mathrm{~kg}$. Based on their body size estimates and overall morphology, our working hypothesis is that the habits of $\uparrow$ Cyonasua would have been similar to those of the living Procyon species; i.e., not strongly specialised for any given locomotory mode or substrate preference.

\section{Materials and methods}

We studied the scapula, humerus, ulna and radius of MLP 04VI-10-1 assigned to $†$ Cyonasua sp. (Fig.1). Specimen MLP 04VI-10-1 was recovered from a fallen block of sediment lying on the beach adjacent to a cliff in a locality known as "Alambrados", at Miramar, Buenos Aires province, Argentina $\left(38^{\circ}\right.$ $14^{\prime} 26.17^{\prime \prime} \mathrm{S}, 57^{\circ} 45^{\prime} 48^{\prime \prime} \mathrm{W}$; Fig. 2). Sedimentological analyses (X-rays made at Centro de Investigaciones Geológicas, UNLPCONICET, Argentina) indicate that MLP 04-VI-10-1 comes from the lower level of the cliff and, thus, is Chapadmalalan (Late Pliocene) in age.

The comparative sample consists of 87 specimens of extant mammals from 19 species belonging to seven families of the Carnivora that are representative of the ecological diversity of the order (Ewer 1973; Van Valkenburgh 1985; Nowak 2005; Wilson \& Mittermeier 2009).

Twenty linear measurements were selected on the forelimb and pectoral girdle skeleton, based on both their availability in the fossil specimen and their potential functional significance (Fig. 3). Measurements were taken with digital calipers; geometric mean size adjustment was applied to raw measurements for size normalisation (i.e., for each individual, each raw value is divided by the geometric mean of all its measurements; Mosimann 1979). The size-normalised data were analysed by principal component analysis (PCA) of the correlation matrix of all taxa, to explore shape variation and segregation in the morphospace.

Each taxon was classified a priori by locomotor mode and substrate preference (six categories), grasping ability (four categories) and digging ability (two categories), based on available

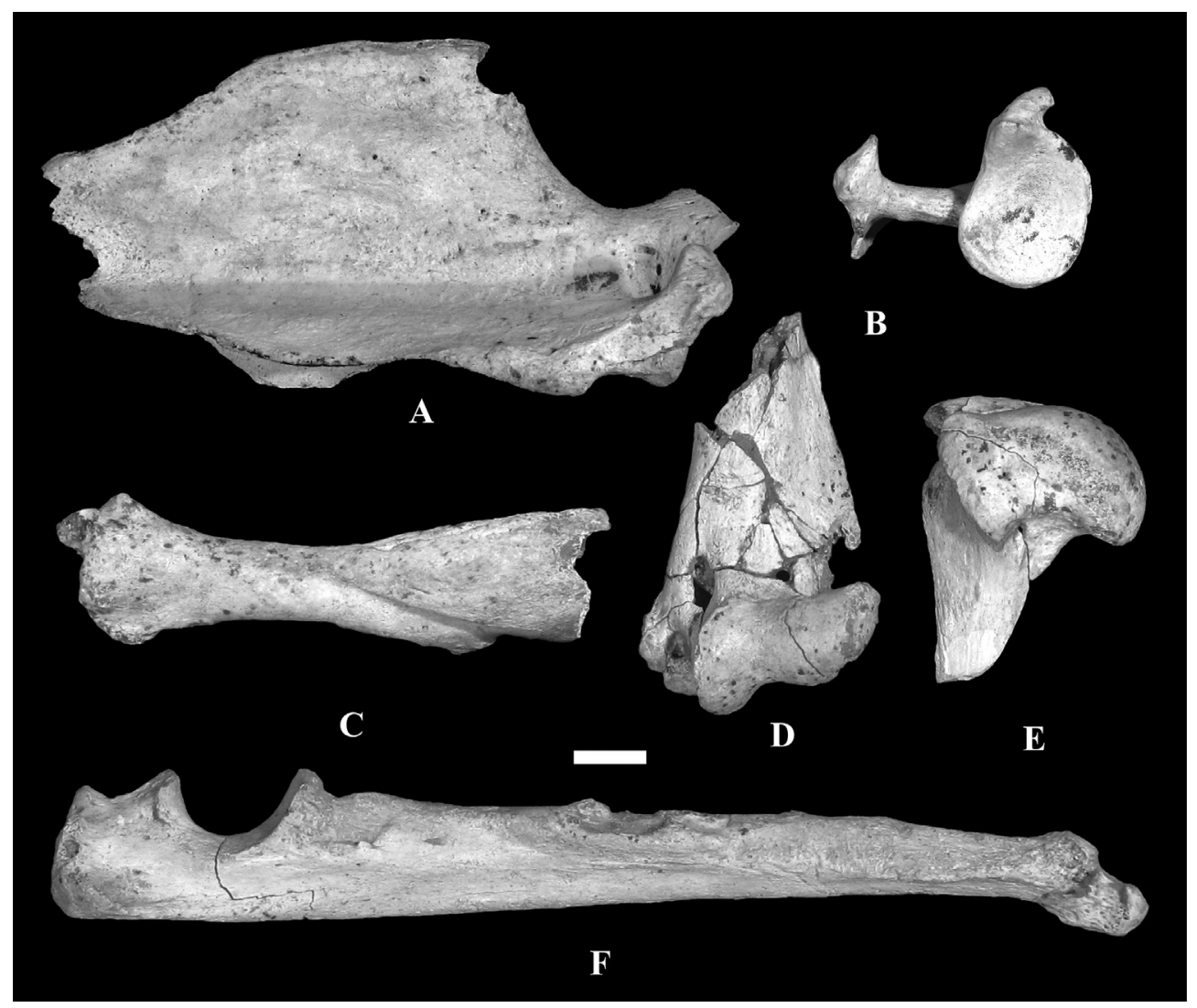

Figure 1 Remains of forelimb and pectoral girdle of †Cyonasua sp. MLP 4-VI-10-1, studied in this work: (A) right scapula, lateral view; (B) right scapula, proximal view; (C) left radius, anterior view; (D) left humerus, anterior view of distal epiphysis; (E) right humerus, medial view of proximal epiphysis; (F) left ulna, medial view. Scale bar $=1 \mathrm{~cm}$. 


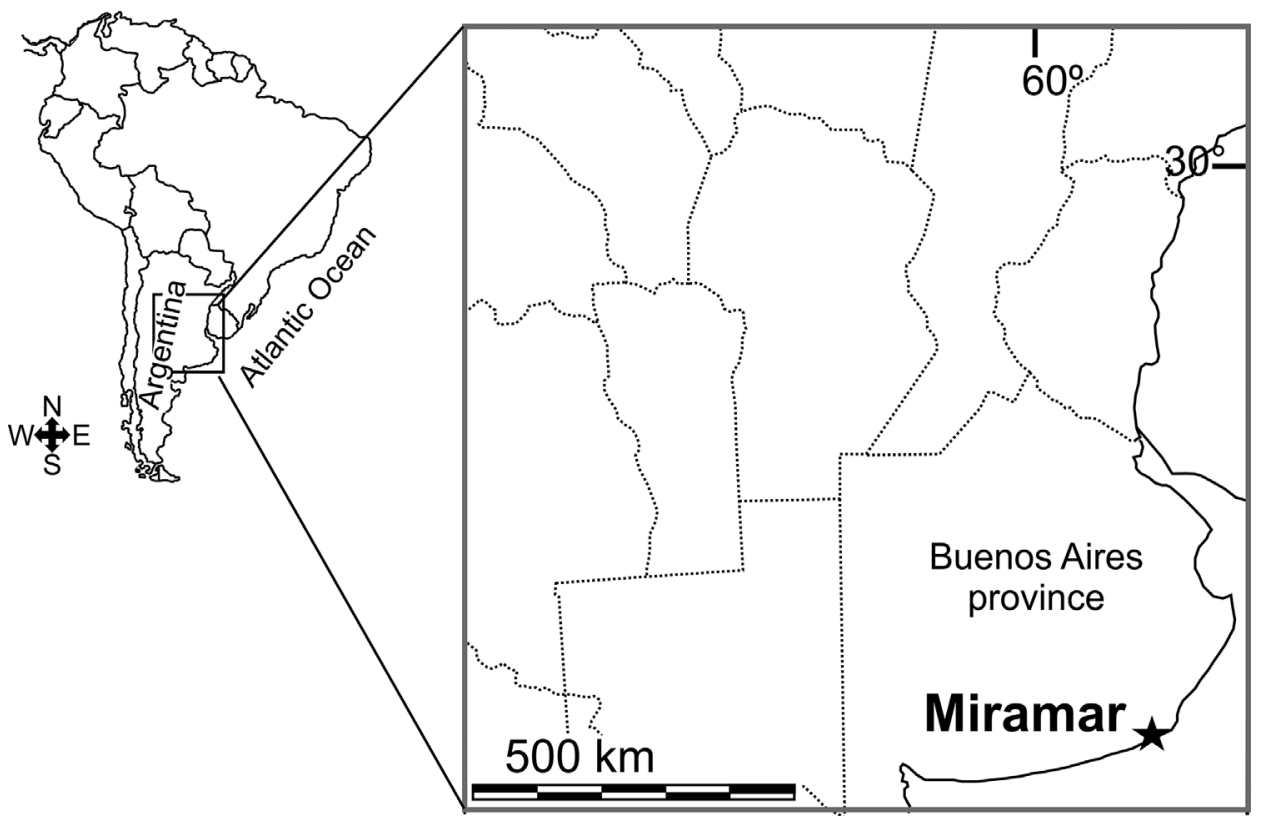

Figure 2 Map of South America showing the Miramar area (star) where $\uparrow$ Cyonasua sp. was recovered.

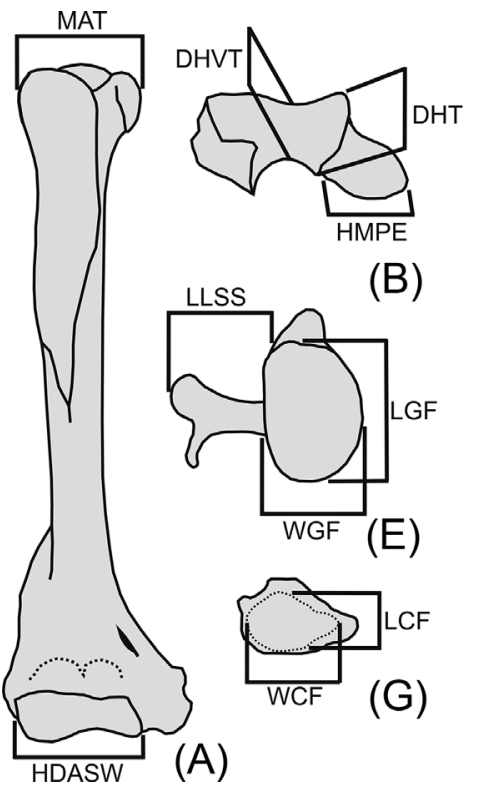

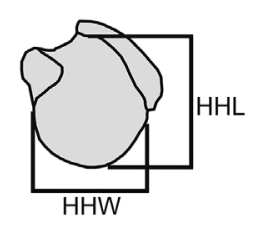

(C)
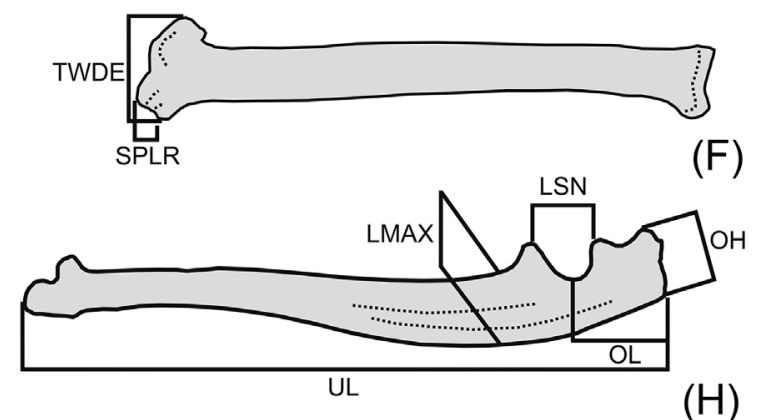

Figure 3 Abbreviations and definition of osteological measurements used in this work. (A) right humerus, anterior view; (B) right humerus, distal view with anterior aspect upward; (C) right humerus, proximal view with anterior aspect upward; (D) right scapula, lateral view; (E) right scapula, glenoid view; (F) right radius, anterior view; $(\mathrm{G})$ right radius, distal view with anterior aspect upward; $(\mathrm{H})$ left ulna, medial view. Abbreviations: Humerus (A-C): DHT = depth of humeral trochlea; DHVT = depth of the humeral trochlear valley; HDASW = humeral distal articular surface width; HHL = humeral head length; HHW = humeral head width; HMPE = medial protrusion of medial epicondyle; MAT = maximum breath between tubercles. Scapula (D, E): LGF = length of the glenoid fossa; LLSS = lateral length of the scapular spine; SNW = scapular neck width; WGF = width of the glenoid fossa. Radius $(F, G):$ LCF = antero-posterior length of carpal fossa; SPLR = length of styloid process of the radius; TWDE $=$ transverse width of the distal radial epiphysis; WCF $=$ latero-medial width of carpal fossa. Ulna $(\mathrm{H})$ : LMAX = antero-posterior maximum length at midshaft of the ulna; LSN = proximo-distal length of semilunar notch; $\mathrm{OH}=$ olecranon height; $\mathrm{OL}=$ olecranon length; $\mathrm{UL}=$ ulnar length.

behavioural information (Table 1). Locomotor and substrate preferences (L \& SP) modes were adapted from Hildebrand (1988), Schutz \& Guralnick (2007) and Van Valkenburgh (1987) as follows:

(1) tree-dweller: species that spend the majority of time on trees;

(2) scansorial or semi-arboreal: species that spend time both on trees and on the ground without a clear preference for either one;
(3) terrestrial-climber: species that spend the majority of their time on the ground and only climb for refuge or eventual feeding;

(4) terrestrial-generalist: species that move on the ground but without any specialization, rarely or never climb or run fast;

(5) terrestrial-cursorial: species that travel far or fast on the ground; and

(6) semi-aquatic: species that swim skillfully and can dive underwater. 
Table 1 List of species used in the analyses with respective substrate preference and locomotory mode, grasping ability and digging ability.

References: ${ }^{1}$ Canevari \& Vaccaro 2007; ${ }^{2}$ Castillo et al. 2013; ${ }^{3}$ Fabre et al. 2013; ${ }^{4}$ Gommper $1995 ;{ }^{5}$ Gompper \& Decker $1998 ;{ }^{6}$ Grzimek et al. 2004; ${ }^{7}$ Helguen et al. 2013; ${ }^{8}$ Jones et al. 2009; ${ }^{9}$ Kasper et al. 2012; ${ }^{10}$ McClearn 1992; ${ }^{11}$ Presley 2000; ${ }^{12}$ Poglayen-Neuwall \& Toweill 1988; ${ }^{13}$ Salesa et al. 2006; ${ }^{14}$ Trapp 1972; ${ }^{15}$ Van Valkenburg 1987; ${ }^{16}$ Wilson \& Mittermeier 2009. When no reference is indicated, category is based on personal observations.

\begin{tabular}{|c|c|c|c|c|c|}
\hline Family & Species & $\begin{array}{l}\text { Substrate preference } \\
\text { and locomotory mode }\end{array}$ & Grasping ability & Digging ability & Body size $(\mathrm{kg})$ \\
\hline \multirow[t]{7}{*}{ Procyonidae } & Procyon cancrivorus & Terrestrial-climbers ${ }^{16}$ & Intermediate ${ }^{3,10}$ & Unspecialised/No ${ }^{16}$ & $8.5^{1}$ \\
\hline & Potos flavus & Tree-dwellers ${ }^{15,16}$ & Well-developed ${ }^{3,10}$ & Unspecialised/No ${ }^{16}$ & $3^{6}$ \\
\hline & Nasuella olivacea & Scansorial $^{16}$ & Poorly-developed & Specialised $^{16}$ & $1.34^{8}$ \\
\hline & Nasua narica & Scansorial $^{16}$ & Poorly-developed ${ }^{3}$ & Specialised $^{10}$ & $4.7^{4}$ \\
\hline & Bassaricyon medius & Tree-dwellers $^{16}$ & Well-developed ${ }^{3}$ & Unspecialised/No ${ }^{10}$ & $1.4^{7}$ \\
\hline & Bassaricyon neblina & Tree-dwellers ${ }^{16}$ & Well-developed ${ }^{3}$ & Unspecialised/No ${ }^{16}$ & $1.4^{7}$ \\
\hline & Bassariscus astutus & Scansorial $^{14,16}$ & Poorly-developed ${ }^{3,12}$ & Unspecialised/No ${ }^{16}$ & $1.01^{8}$ \\
\hline \multirow[t]{3}{*}{ Mustelidae } & Eira barbara & Scansorial $^{16}$ & Poorly-developed ${ }^{2,10}$ & Unspecialised/No ${ }^{11,16}$ & $4.13^{8}$ \\
\hline & Galictis cuja & Terrestrial-generalist $^{16}$ & Poorly-developed ${ }^{3}$ & Unspecialised/No ${ }^{16}$ & $1.75^{16}$ \\
\hline & Lontra longicaudis & Semiaquatic $^{16}$ & Intermediate $^{14}$ & Unspecialised/No ${ }^{16}$ & $6.55^{8}$ \\
\hline \multirow[t]{2}{*}{ Mephitidae } & Conepatus chinga & Terrestrial-generalist $^{16}$ & Poorly-developed ${ }^{2}$ & Specialised $^{2,9}$ & $2^{8}$ \\
\hline & Conepatus sp & Terrestrial-generalist $^{16}$ & Poorly-developed ${ }^{2}$ & Specialised $^{2,9}$ & $2^{8}$ \\
\hline Viverridae & Arctictis binturong & Tree-dwellers ${ }^{15,16}$ & Intermediate & Unspecialised/No ${ }^{16}$ & $13^{8}$ \\
\hline Ursidae & Tremarctos ornatus & Terrestrial-climbers ${ }^{16}$ & Intermediate $^{13}$ & Unspecialised/No ${ }^{16}$ & $70^{16}$ \\
\hline Canidae & Lycalopex griseus & Terrestrial-cursorial $^{16}$ & Non-developed & Unspecialised/No ${ }^{16}$ & $3.75^{16}$ \\
\hline Felidae & Leopardus geoffroyi & Terrestrial-climbers ${ }^{16}$ & Poorly-developed & Unspecialised/No ${ }^{16}$ & $5^{16}$ \\
\hline
\end{tabular}

Table 2 Contribution of the variables to each principal component (PC).

\begin{tabular}{lcc}
\hline Variable & PC1 & PC2 \\
\hline LFG & 0.5627 & 0.5913 \\
WGF & -0.04122 & 0.01073 \\
LLSS & 0.4901 & -0.3246 \\
SNW & -0.3481 & 0.4131 \\
HHL & 0.3829 & 0.0726 \\
HHW & 0.3653 & -0.0729 \\
HDASW & -0.4003 & 0.6645 \\
DHVT & 0.918 & -0.005232 \\
DHT & 0.6428 & -0.4565 \\
HMPE & -0.4565 & 0.5504 \\
MAT & 0.4618 & 0.5739 \\
UL & 0.02472 & -0.8084 \\
LMAX & -0.6537 & -0.02688 \\
OH & 0.4986 & 0.1697 \\
OL & -0.03907 & 0.3874 \\
LSN & 0.6889 & 0.2877 \\
LCF & -0.05637 & 0.52 \\
WCF & -0.04732 & 0.08753 \\
TWDE & -0.1901 & 0.09668 \\
SPLR & -0.567 & -0.5406 \\
\hline Eigenvalue & 4.31317 & 3.41404 \\
Total variance explained $(\%)$ & 21.566 & 17.07 \\
\hline & & \\
\hline & & \\
\hline
\end{tabular}

Regarding grasping ability (GA), taxa were grouped into four categories as described by Fabre et al. (2013), following published information (e.g., Poglayen-Neuwall \& Toweill 1988; Taylor 1989; McClearn 1992; Presley 2000; Castillo et al. 2013). GA categories are:

(1) well-developed GA: species that can grasp objects using only one hand;
(2) intermediate GA: species able to grasp objects only by using both forefeet at once, and have fine control of digit movements;

(3) poorly-developed GA: species with little or no manipulation of food with their forefeet alone; they frequently use their paws in combination with the ground to achieve manipulation and grasp is mainly used for climbing; and

(4) non-developed GA: species with no grasping ability.

The categories considered for digging ability (DigA) are:

(1) specialised DigA: species that dig for prey and, also, to build their burrows, with well-developed forelimbs armed with long claws;

(2) unspecialised/no DigA: species able to dig in soft ground to build their burrows, but without morphological specialisation, and species with no DigA.

The classification of studied taxa according to these variables is detailed in Table 1 .

Significant differences between L \& SP categories across taxa were assessed using multivariate analysis of variance (MANOVA) and a posteriori multiple comparisons made using Bonferroni correction. Multivariate canonical analysis (discriminant analysis, DA) was used to evaluate the contribution of the morphometric variables considered to the differentiation among L \& SP, GA and DigA categories, and to obtain probable category assignments for $†$ Cyonasua sp. regarding each of these abilities. Analyses were carried out using the software PAST 3.04 (Hammer et al. 2001) and Statistica 7.0 (StatSoft Inc.). Graphics for Figure 4 were performed in R with package "ggplot2" (Wickham 2009).

\subsection{Carnivorans used for comparisons}

1.1.1. Repository abbreviations. AMNH, American Museum of Natural History, New York, USA; EMG, Colección privada de "Enrique Manuel Gonzalez", Sección Mamíferos del 


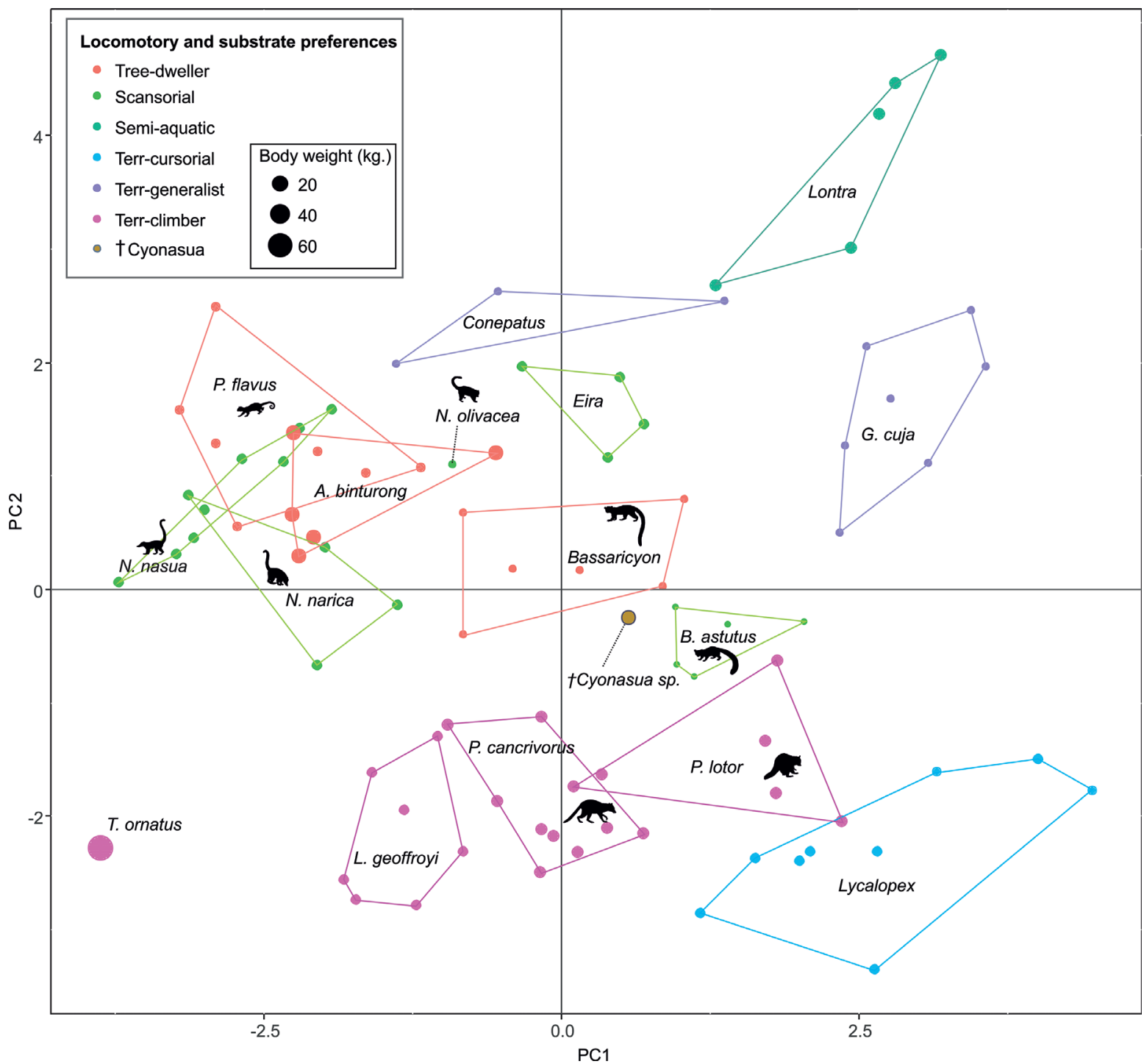

Figure 4 Results of PCA of living carnivorans and $†$ Cyonasua sp. MLP 4-VI-10-1. Polygons group genera or species with their scientific names. Members of Procyonidae are identified by their silhouettes. Body mass represented by the size of circles; locomotor and substrate preferences mode are indicated by different colours (see key).

Table 3 Pairwise comparisons among substrate preferences and locomotory modes. Wilks' lambda $=0.054 ; \mathrm{P}<0.0001$

\begin{tabular}{lllllll}
\hline Categories & $\begin{array}{l}\text { Terrestrial- } \\
\text { climbers }\end{array}$ & $\begin{array}{l}\text { Tree- } \\
\text { dwellers }\end{array}$ & Scansorial & $\begin{array}{l}\text { Terrestrial- } \\
\text { noncursorial }\end{array}$ & $\begin{array}{l}\text { Semi- } \\
\text { aquatic }\end{array}$ & $\begin{array}{l}\text { Terrestrial } \\
\text { cursorial }\end{array}$ \\
\hline Terrestrial-climbers & 0 & $2.69 \mathrm{E}-14$ & $1.21 \mathrm{E}-14$ & $7.28 \mathrm{E}-13$ & $1.04 \mathrm{E}-13$ & $6.07 \mathrm{E}-05$ \\
Tree-dwellers & $2.69 \mathrm{E}-14$ & 0 & 1 & $6.30 \mathrm{E}-05$ & $2.01 \mathrm{E}-06$ & $2.84 \mathrm{E}-11$ \\
Scansorial & $1.21 \mathrm{E}-14$ & 1 & 0 & $2.75 \mathrm{E}-05$ & $2.79 \mathrm{E}-06$ & $2.92 \mathrm{E}-11$ \\
Terrestrial-noncursorial & $7.28 \mathrm{E}-13$ & $6.30 \mathrm{E}-05$ & $2.75 \mathrm{E}-05$ & 0 & 0.0238636 & $7.06 \mathrm{E}-08$ \\
Semi-aquatic & $1.04 \mathrm{E}-13$ & $2.01 \mathrm{E}-06$ & $2.79 \mathrm{E}-06$ & 0.0238636 & 0 & $7.64 \mathrm{E}-07$ \\
Terrestrial cursorial & $6.07 \mathrm{E}-05$ & $2.84 \mathrm{E}-11$ & $2.92 \mathrm{E}-11$ & $7.06 \mathrm{E}-08$ & $7.64 \mathrm{E}-07$ & 0 \\
\hline
\end{tabular}

Museo Nacional de Historia Natural (MNHN, Montevideo, Uruguay); MACN, Museo Argentino de Ciencias Naturales 'Bernardino Rivadavia'; Ciudad Autónoma de Buenos Aires, Argentina; MLP, Departamento Científico de Paleontología de Vertebrados, Museo de La Plata, La Plata, Argentina; MNHN, Museo Nacional de Historia Natural, Montevideo, Uruguay; USNM, National Museum of Natural History, Smithsonian Institution, Washington, DC, USA; ZOOBA-M, Zoológico de Buenos Aires, sección Mamíferos, Ciudad Autónoma de Buenos Aires, Argentina; ZVC-M, Facultad de Ciencias, Universidad de la República, Montevideo, Uruguay.
1.1.2. Specimens. Procyonidae: Procyon cancrivorus MACN 32254, MLP 2110, MLP 1.I.03.25, MNHN 1229, MNHN 1268, MNHN 2714, MNHN 3146, MNHN 3264, MNHN 3285;

Procyon lotor AMNH 135185, AMNH 237438, AMNH 238271, AMNH 245498, AMNH 245620, MACN 23573;

Potos flavus AMNH 266597, AMNH 266599, AMNH 267050, AMNH 267607, AMNH 267608, MLP 1740, ZVC-M 5730 ; 
Table 4 Standardised discriminant coefficients for substrate preferences and locomotory mode.

\begin{tabular}{lcr}
\hline Variable & DF1 & \multicolumn{1}{c}{ DF2 } \\
\hline LGF & 0.17870 & 0.244940 \\
WGF & -0.09782 & 0.232756 \\
LLSS & -0.48008 & 0.124043 \\
SNW & -0.44580 & 0.213078 \\
HHL & -0.17848 & 0.016263 \\
HHW & -0.05205 & -0.105694 \\
HDASW & 0.47837 & -0.573643 \\
DHVT & -0.12023 & 0.254601 \\
DHT & -0.65459 & 0.519370 \\
HMPE & -0.65470 & 0.223143 \\
MAT & 0.20425 & 0.134494 \\
UL & -1.53033 & -0.296546 \\
LMAX & -0.32022 & -0.353254 \\
OH & -0.62170 & 0.874273 \\
OL & 0.12159 & 0.502761 \\
LSN & 0.15470 & -0.206826 \\
LCF & -0.65578 & 0.367907 \\
WCF & -0.20814 & 0.282947 \\
TWDE & -0.32394 & -0.288519 \\
SPLR & -0.76257 & -0.231263 \\
\hline Eigenvalue & 14.85167 & 9.27 \\
\% cumulative proportion & 50.58 & \\
\hline & & \\
\hline
\end{tabular}

\section{Nasuella olivacea USNM 372855;}

Nasua narica AMNH 14062, USNM A 22810, USNM 49644, USNM 257314;

Nasua nasua AMNH 134007, AMNH 255871, AMNH 30203, MACN 5.12, MACN 33269, MACN 25862, ZOOBA-M0084, ZOOBA-M-0085;

Bassaricyon medius USNM 305748, USNM 305749, USNM 310666, USNM 307037, USNM 598997;

Bassaricyon neblina USNM 598996;

Bassariscus astutus AMNH 135963, AMNH 135965, AMNH 135966, AMNH 137030, AMNH 137053.

Mustelidae: Eira barbara MLP 1013, MNHN 5518, AMNH 95374, AMNH 133953;

Galictis cuja MACN 23519, MLP 2020, MLP 15.V.97.42, MNHN 1158, MNHN 2548, MNHN 2696, MNHN 3233;

Lontra longicaudis EMG 1971, MACN 71, MACN 47218, MLP 1959;

Lontra provocax MACN 20821.

Mephitidae: Conepatus sp. MLP 1015, MLP 1.II.95.1; Conepatus chinga MACN 28.20.

Viverridae: Arctictis binturong AMNH 22906, AMNH 35469, AMNH 90279, AMNH 119600, AMNH 197252.

Ursidae: Tremarctos ornatus MLP 1.I.03.62.

Felidae: Leopardus geoffroyi MLP 1884, MLP 1998, MLP

9.X.92.1, MLP 20.V.02.1, MLP 27.XII.01.18, MLP

27.XII.01.17, MLP 27.X11.01.22.

Canidae: Lycalopex gymnocercus MACN 23910, MACN 24259, MACN 33267, MACN 34317, MLP 190, MLP 1967, MLP 15.V.96.5;

Lycalopex griseus MLP 1889, MLP 1903.

\section{Results}

The first two principal components (PC) explain $38.64 \%$ of the total variation of the sample (PC1: $21.57 \%$; PC2: $17.07 \%$; Table 2); the relatively small proportion of explained variance is to be expected because of the size-normalisation employed. As presented in Table 2, the variables with highest loading on PC1 were depth of the humeral trochlear valley (depth of humeral distal articular surface, DHTV), proximodistal length of the semilunar notch (LSN), maximum anteroposterior length of the ulnar diaphysis (LMAX) and depth of the humeral trochlea (DHT). Thus, the taxa with positive scores on this axis possess humeri with relatively broad humeral valleys and more distally projected trochlea, and ulnae with relatively wide semilunar notches and anteroposteriorly narrower diaphysis; whilst those with negative scores have opposite features. With respect to PC2, the variables with higher loading were humeral distal articular surface width (HDASW) and ulnar length (UL). Thus, the taxa with positive scores on the second axis have relatively wide humeral distal articular surfaces and relatively short ulnae, whilst those with negative scores present opposite features. In the morphospace of the first two PCs, most taxa were clearly grouped by genus, and generally separated from the others, except the overlapping scansorial and tree-dwelling species. Furthermore, the distribution of taxa shows that neither PC is correlated with body size; for instance, on Figure 4 it can be observed that along PC1, Tremarctos ornatus $(70 \mathrm{~kg})$ is near the small kinkajou Potos flavus (3 kg).

\subsection{Locomotor and substrate preferences}

The taxa were arranged in a gradient from terrestrial-cursorial (positive PC1 and negative PC2 scores) to tree-dwelling and scansorial forms (negative PC1 and positive PC2 scores), with terrestrial-climbing, terrestrial-generalist and semi-aquatic taxa distributed between these extremes; without any visible pattern related to body size. Positive PC1 values were occupied by the terrestrial-cursorial Lycalopex griseus and Ly. gymnocercus, the terrestrial-generalist $G$. cuja and the semiaquatic Lontra longicaudis and Lo. provocax; and negative values were occupied mostly by tree-dwellers (Potos flavus, Arctictis binturong), the scansorials Nasua nasua and $N$. narica and terrestrial-climbing taxa (Tremarctos ornatus, Leopardus geoffroyi). Taxa with a variety of substrate preference and locomotory modes, including the terrestrial-generalist Conepatus, the terrestrial-climbing Procyon cancrivorus, the scansorial Eira barbara and the tree-dweller Bassaricyon, presented nearzero scores on this axis. Along PC2, two distinct major groups include, on the one hand and towards positive values, semiaquatic, terrestrial-generalist, and several scansorial and treedwelling genera (Fig. 4); on the other hand, terrestrial-climbers and terrestrial-cursorials had negative PC2 scores. In this context, $\uparrow$ Cyonasua sp. occupied a unique position in the morphospace; its humerus, with a relatively wide trochlear valley and a distally projected trochlea, is combined with a moderately narrow ulna that presents a medium-width semilunar notch. Its position was among other procyonids such as the scansorial Bassariscus and the tree-dwelling Bassaricyon and, at the same time, relatively near to the terrestrial-climbing Procyon species.

The MANOVA showed statistically significant differences among L \& SP (Wilks' lambda $=0.054, \mathrm{p}<0.001$ ); pairwise comparisons demonstrated significant differences between the terrestrial-climbing, terrestrial-generalist, terrestrial-cursorial and semi-aquatic categories, but not between tree-dwellers and scansorials (see Table 3). In agreement with these results, the DA showed good differentiation between terrestrial-cursorial, 


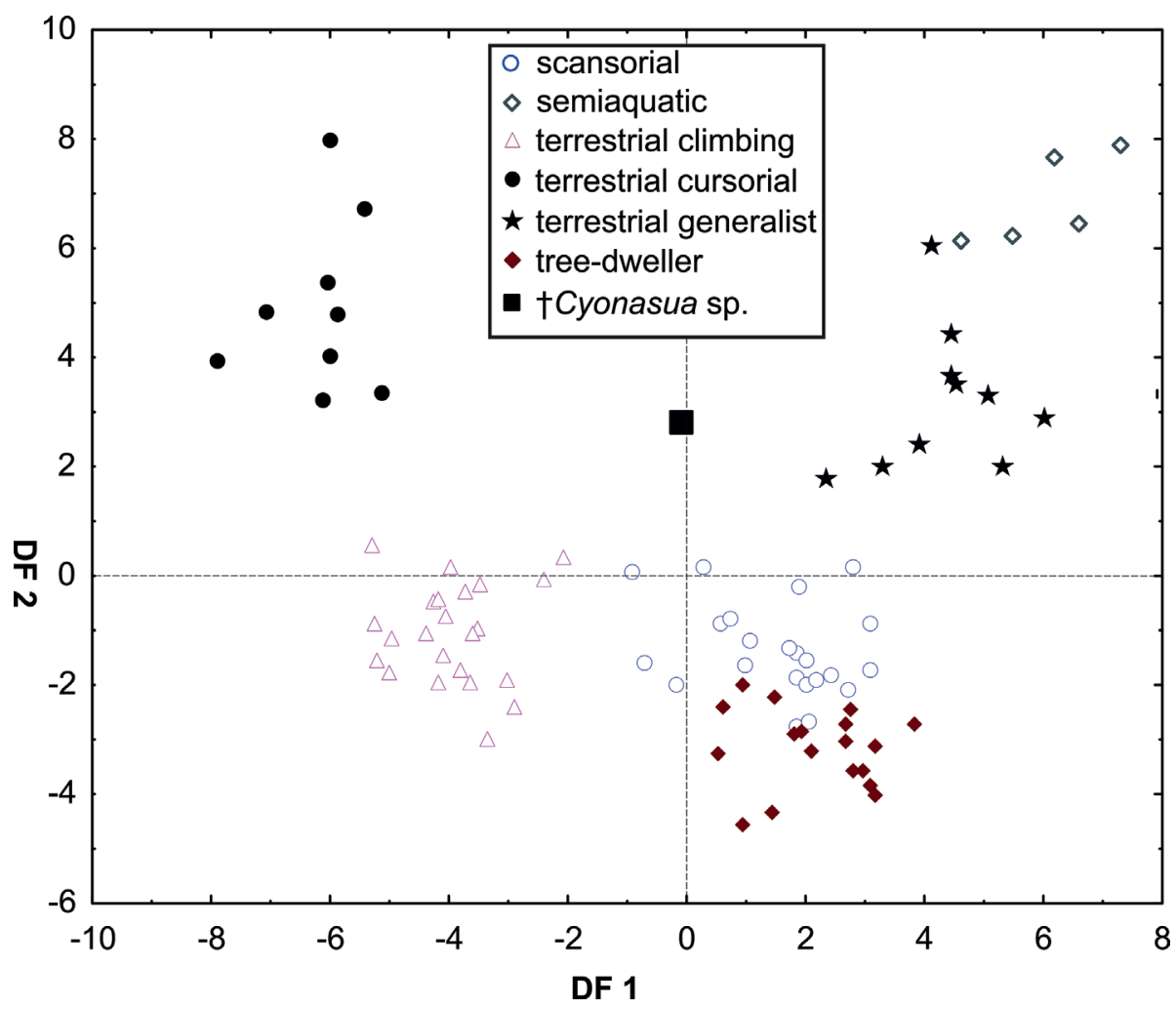

Figure 5 Scatterplot of first two axes of a discriminant analysis of substrate preference and locomotory modes.

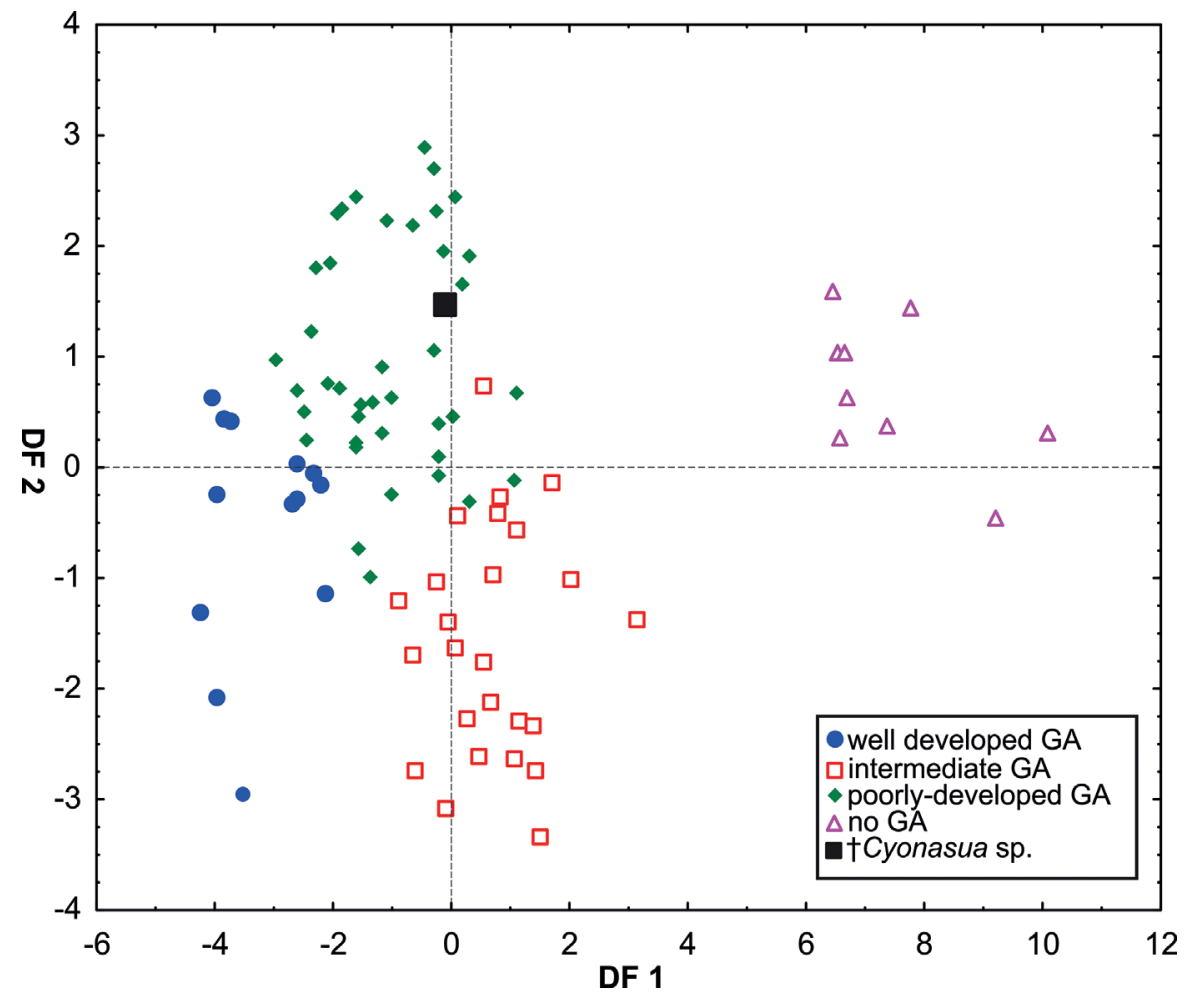

Figure 6 Scatterplot of first two axes of a discriminant analysis of grasping ability.

terrestrial-climbing, terrestrial-generalist and semiaquatic categories, but overlapping between the scansorial and tree-dwelling taxa. The variables that most contributed to the discrimination of categories were ulnar length (UL), length of the radial styloid process (SPLR), antero-posterior length of the carpal fossa (LCF), depth of the humeral trochlea (DHT) and medial protrusion of the humeral medial epicondyle (HMPE) (first root), and olecranon height $(\mathrm{OH})$ (second root) (Table 4). Posterior probabilities classified $†$ Cyonasua sp. as terrestrial-generalist (terrestrial-generalist: $\sim 0.8$; terrestrial-climber: $\sim 0.1$ and scansorial: $\sim 0.1$ ) (Fig. 5).

\subsection{Grasping ability}

The DA showed differences amongst all GA categories (Wilks' Lambda: 0.0188837, p < 0.0001) (Fig 6). The variables that most contributed to the discrimination were depth of the 
Table 5 Contribution of the variables to each discriminant function for grasping ability.

\begin{tabular}{lrr}
\hline Variable & \multicolumn{1}{c}{ DF1 } & \multicolumn{1}{c}{ DF2 } \\
\hline LFG & 0.022753 & -0.055142 \\
WGF & -0.048770 & -0.313758 \\
LLSS & 0.119421 & 0.013714 \\
SNW & 0.001554 & -0.184695 \\
HHL & -0.005334 & -0.196843 \\
HHW & -0.015777 & 0.020115 \\
HDASW & -0.455127 & -0.050773 \\
DHVT & 0.183234 & 0.045864 \\
DHT & 0.496756 & 0.166601 \\
HMPE & -0.185282 & 0.137362 \\
MAT & -0.082093 & -0.102997 \\
UL & 0.131543 & -0.205810 \\
LMAX & -0.140314 & 0.004181 \\
OH & 0.116483 & 0.088747 \\
OL & 0.024650 & 0.194891 \\
LSN & 0.057167 & 0.013418 \\
LCF & -0.152913 & -0.078812 \\
WCF & -0.010752 & 0.321011 \\
TWDE & 0.048955 & 0.177385 \\
SPLR & -0.052577 & 0.006153 \\
\hline Eigenvalue & 8.14398 & 1.56989 \\
\% cumulative proportion & 74.26 & 88.57 \\
\hline & & \\
\hline
\end{tabular}

humeral trochlea (DHT), width of the humeral distal articular surface (HDASW) (first root), and latero-medial width of the carpal fossa of the radius (WCF) (second root) (Table 5). Posterior probabilities assigned †Cyonasua sp. to the poorly developed GA category ( $\mathrm{p}>0.99$ ).

\subsection{Digging ability}

The two DigA categories were well differentiated (Wilks' Lambda $=0.1609736, \mathrm{p}<0.00001)$, with no overlap. The variables that most contributed to discrimination were medial protrusion of the humeral medial epicondyle (HMPE) and olecranon length (OL) (Table 6). The taxa with greater digging ability (specialised-DigA: Nasuella olivacea, Nasua nasua, $N$. narica and Conepatus) occupied extreme negatives scores (from -6.6 to -3.4 ) and were associated with a well-protruding medial epicondyle and long olecranon; the unspecialised (noDigA) taxa had near zero and positive scores (from -1.04 to 3.53), reflecting a scarcely protruding medial epicondyle and shorter olecranon. Posterior probabilities assigned $\uparrow$ Cyonasua sp. to the no-DigA category $(\mathrm{p}=1)$.

\section{Discussion}

\subsection{Locomotory and substrate preference}

Although several authors (see Grzimek et al. 2004; Nowak 2005) have classified procyonids as good climbers with a generalised morphology, this analysis showed morphological differences related to their substrate preferences and locomotory mode. As mentioned above, body size was not detected as being a primary influence for substrate preference patterns. The skeletal morphology of Procyon and Nasua shows features well suited for terrestrial locomotion and, to a lesser extent, for climbing and moving in trees. In particular, Procyon has an elongated ulna and narrow distal humeral articular surface, which have been primarily related to ground locomotion (Andersson 2004; Samuels et al. 2013). However, in Nasua,
Table 6 Contribution of each variable to discriminant function for digging ability.

\begin{tabular}{lc}
\hline Variable & DF 1 \\
\hline LFG & 0.051571 \\
WGF & 0.086348 \\
LLSS & 0.195023 \\
SNW & -0.057463 \\
HHL & 0.073283 \\
HHW & 0.19588 \\
HDASW & -0.029465 \\
DHVT & 0.151464 \\
DHT & 0.077644 \\
HMPE & -0.408718 \\
MAT & 0.038282 \\
UL & 0.139298 \\
LMAX & -0.107026 \\
OH & 0.176335 \\
OL & -0.295026 \\
LSN & 0.145352 \\
LCF & -0.012739 \\
WCF & 0.052219 \\
TWDE & -0.091073 \\
SPLR & -0.046485 \\
\hline Eigenvalue & 5.212 \\
cumulative proportion & 100 \\
\hline &
\end{tabular}

traits such as the medium distal extension of the humeral trochlea, the moderately deep trochlear valley of the humerus and the dimensions of the semilunar notch, differ from the condition observed in forms whose forelimbs are used primarily for running and optimised for parasagittal movement (e.g. Lycalopex). In addition, Nasua, considered as both scansorial and a ground-dweller (McClearn 1992; Glaston 1994; Beisiegel 2001), presents certain features similar to those of tree-dwellers (e.g., Potos), including a wide antero-posterior ulnar shaft, required for insertion of several flexor muscles that function in both climbing and digging (Stalheim-Smith 1984; Vizcaíno \& Milne 2002; Toledo et al. 2013).

The intermediate position of †Cyonasua sp. in the PCA morphospace reflects a morphology associated with some stability of the elbow articulation and relatively restricted lateromedial mobility; but not as much as the condition of cursorials, in which movements are restricted to the anteroposterior plane (hinge-like elbow joint) (Taylor 1974; Andersson 2004). Although it does not possess full scansorial and treedweller features, the moderately thick ulnar diaphysis of $\dagger$ Cyonasua sp. suggests considerable surface area for attachment of carpal and digital extensor and flexor muscles which are, as mentioned above, involved in arboreal locomotion and/or active use of the forefeet (Davis 1964; Fleagle 1998; Evans \& De Lahunta 2013). The pairwise comparisons and DA showed that no significant differences exist between treedwellers and scansorial taxa, at least regarding the traits measured in this work. This could be a reflection of the fact that the forelimb and pectoral girdle do not provide enough information to separate categories with intermediate features (Samuels et al. 2013); indeed, similar results have been obtained in previous studies (Ercoli et al. 2012). In addition, as previously mentioned, climbing and digging activities are, to some extent, associated with similar musculoskeletal morphological features (Stalheim-Smith 1984; White 1997; Argot 2001; Sargis 2002; Candela \& Picasso 2008). 
$\dagger$ Cyonasua sp. does not fall into any of the previously defined morphospaces regarding L \& SP groups, although our results suggest that its capabilities could be similar to those of the terrestrial-generalists Galictis cuja and Conepatus. Its known skeletal morphology presents similarities to species that occupy a variety of habitats, and whose forelimbs are moderately specialised for running, galloping and digging and, to a lesser extent, for climbing and manipulating prey (Yensen \& Tarifa 2003; Donadio et al. 2004; Wilson \& Mittermeier 2009; Ercoli et al. 2014). It is worth noting that the variables contributing to the separation between locomotory and substrate preference modes are not easy to integrate into a straightforward morphofunctional interpretation. Features associated with the tree-dweller and scansorial categories, such as the medial protrusion of the medial epicondyle, were associated in the discriminant analysis with traits related to cursorial habits, such as ulnar length and depth of the humeral trochlea. This is partly to be expected, as the forelimb, which has often been used as a good indicator of locomotor ecology (Gonyea 1978; Van Valkenburgh 1987; Argot 2001; Croft \& Anderson 2008), also participates in other activities, as discussed below.

\subsection{Grasping ability}

In addition to playing important roles in posture and locomotion, the forelimb also participates in foraging and other activities. In this sense, manual dexterity and joint stability during locomotion appear to be mutually exclusive functions (Andersson 2004). The use of the forelimbs for grasping is very common among carnivorans, especially in those that show an arboreal life (Fabre et al. 2013). Thus, it should be expected that species with tree-dwelling (e.g. P. flavus, B. neblina, B. medius and A. binturong), scansorial ( $N$. nasua, $N$. narica, amongst others) and terrestrial-climbing ( $P$. cancrivorus, $P$. lotor and L. geoffroyi) locomotory modes are also capable of grasping to some extent.

Our results show that species without grasping ability (nonGA ability, such as pampas foxes) are wide apart from those able to grasp, which are also, significantly, those that show some association with arboreal substrates. Discrimination was mostly correlated with variables associated with elbow joint stability (DF1); thus, tree-dwellers (Potos and Bassaricyon) with well-developed grasping ability showed traits related to a poorly stabilised joint and pronation-supination capability (Fabre et al. 2013). On the other hand, the non-grasping forms, which included the cursorial Lycalopex, were associated with a narrower and deeper humeral articular surface, indicating a stabilised joint and restricted pronation-supination movements. The second discrimination axis (DF2) was associated mainly with the width of the distal radial articular surface, which is involved in wrist movement and pronation-supination movements (Andersson 2003). This factor separated species with poor or no grasping ability, which were associated with a medio-laterally wide articular surface for the scapholunar that could reduce the medio-lateral deviation of the wrist (Lynch 2012). Given that the variables that contributed to group separation are concordant with this morphofunctional interpretation, it is possible to infer, with some confidence, that †Cyonasua $\mathrm{sp}$. would present a moderately stabilised elbow joint and restricted (at least latero-medially) wrist movement and, thereby, poorly-developed grasping ability, but not so limited as to allow it to be classified as no-GA.

\subsection{Digging ability}

The majority of species in our comparative sample display some degree of digging ability, either in building sheltering burrows or for foraging (Nowak 2005). Thus, we established only two categories (specialised vs. non-specialised) to better understand the reflection of this specialisation on skeletal morphology. It was easy to differentiate DA and DigA amongst the groups. The variables (medial protrusion of medial epicondyle and olecranon length), which present negative loads, are strongly associated with mechanical advantage of the muscles involved in elbow extension and manual and digital flexion (Taylor 1974; Vizcaíno et al. 1999) which, in turn, are directly related to development of forces during digging (Elissamburu \& Vizcaíno 2004). Accordingly, specialised diggers such as Nasua and Conepatus occupied high negative values, whilst all other species (unspecialised/no-DigA) had low negative to positive scores. Thus, the position of $†$ Cyonasua sp. suggests unspecialised digging ability.

\subsection{Summary}

In summary, all the analyses performed here point to the interpretation of $\dagger$ Cyonasua sp. as having a moderately stabilised elbow joint with poor pronation-supination capabilities, although some climbing skills, associated with its restricted grasping ability, cannot be ruled out. Although $†$ Cyonasua was larger than any recent procyonid species, eventual climbing for some activities (e.g., rest, protection or foraging) was allowed for by its locomotor apparatus. We propose that $\dagger$ Cyonasua sp. could have had generalised habits. This agrees with a previous analysis (Tarquini et al. 2012), in which $\dagger$ Cyonasua sp. was found to be similar to the extant Procyon, as both genera were close in terms of substrate preference and locomotory mode, as well as grasping ability, and both are non-specialised diggers.

The capabilities hypothesised herein for $†$ Cyonasua are in agreement with what it is known about the plant community occurring during the Chapalmalalan. Erra et al. (2010) reported palaeocommunities dominated by palms (Arecaceae), as well as by C4-type Gramineae and Ulmaceae, Celtidaceae and Moraceae from silicophytoliths in palaeosoils in the upper section of the Chapadmalalan. These plants would indicate bushy savannas with a dry season and a temperature of over $10^{\circ} \mathrm{C}$ in the cold season. The Chapadmalalan fauna is very diverse, indicating disparate environments; e.g., the presence of argyrolagid marsupials and abundance of fossorial rodents, interpreted as indicators of arid and semi-arid conditions, as well as certain didelphid marsupials related to conditions similar to the current ones, but rainier and with the presence of gallery forests or forest patches (Cione et al. 2015).

\section{Conclusions}

- Our analysis shows that the forelimb and pectoral girdle features of carnivorans studied in this work allow for differentiation of most of the a priori categories used in this work.

- †Cyonasua sp. occupied a unique position in the PCA morphospace, which suggests that its forelimb was somewhat different in morphofunctional patterns as compared to the extant carnivorans included in our sample.

- According to the analyses of substrate preference and locomotory mode, †Cyonasua was not a specialised form but, rather, generalised. However, it would have possessed some degree of grasping ability compatible with climbing.

- Although $†$ Cyonasua seems not to have been a specialised digger, its morphology does not rule out some digging capacity. 


\section{Acknowledgements}

We thank A. I. Olivares and M. Reguero (MLP), D. Flores and S. Lucero (MACN), E. M. González (MNHN), S. Riverón, Facultad de Ciencias (Udelar), E. Westwig (AMNH) and D. P. Lunde and J. Ososky (NMNH) for kindly providing access to the collections under their care. We also thank R. Fariña and S. Vizcaíno for valuable suggestions on an early version of this MS. JT would like to thank the American Museum of Natural History's Theodore Roosevelt Memorial Fund for financial support of the research on North American mammals and CONICET for grant support. This is a contribution to projects PICT 0804 and PIP 0436.

\section{References}

Allen, J. A. 1876. Description of a new generic type (Bassaricyon) of Procyonidae from Costa Rica. Proceedings of the Academy of Natural Sciences of Philadelphia 28, 20-23.

Ameghino, F. 1885. Nuevos restos de mamíferos fósiles oligocenos recogidos por el Profesor Scalabrini y pertenecientes al Museo provincial de Paraná. Boletín de la Academia Nacional de Ciencias de Córdoba 8, 3-207

Ameghino, F. 1904. Nuevas especies de mamíferos cretáceos y terciarios de la República Argentina. Anales de la Sociedad Científica Argentina 20, 56-58

Ameghino, F. 1908. Las formaciones sedimentarias de la región litoral de Mar del Plata y Chapalmalán. Anales del Museo Nacional de Buenos Aires 10(3ra. Sección), 343-428.

Ameghino, C. \& Kraglievich, J. 1925. Un nuevo prociónido cercoleptoide en el Pampeano inferior de la Argentina, Brachynasua meranii, n. gen., n. sp. Comunicaciones Museo Nacional de Historia Natural, "Bernadino Rivadavia", Buenos Aires 2, 181-91.

Andersson, K. 2003. Aspects of locomotor evolution in the Carnivora (Mammalia). Doctoral Thesis, Uppsala University, Sweden. 20 pp.

Andersson, K. 2004. Elbow joint morphology as a guide to forearm function and foraging behaviour in mammalian carnivores. Zoological Journal of the Linnean Society 142, 91-104.

Argot, C. 2001. Functional-adaptive anatomy of the forelimb in the didelphidae, and the paleobiology of the paleocene marsupials Mayulestes ferox and Pucadelphys andinus. Journal of Morphology 247, 51-79.

Beisiegel, B. M. 2001. Notes on the coati, Nasua nasua (Carnivora: Procyonidae) in an Atlantic forest area. Brazilian Journal of Biology 61, 689-92.

Burmeister, G. 1891. Adiciones al examen crítico de los mamíferos fósiles tratados en el artículo IV anterior. Anales del Museo Nacional de Buenos Aires 3, 375-99.

Cabrera, A. 1936. Un nuevo carnívoro del Chapadmalense de Miramar. Notas del Museo de La Plata, Paleontología 7, 303-08.

Candela, A. M. \& Picasso, M. B. 2008. Functional anatomy of the limbs of Erethizontidae (Rodentia, Caviomorpha): indicators of locomotor behaviour in Miocene porcupines. Journal of Morphology 269, 552-93.

Canevari, M. \& Vaccaro, O. 2007. Guía de mamíferos del sur de América del Sur. $413 \mathrm{pp}$.

Castillo, D. F., Luengos Vidal, E. M., Caruso, N. C., Lucherini, M. \& Casanave, E. B. 2013. Denning ecology of conepatus chinga (Carnivora: Mephitidae) in a grassland relict of central Argentina. Mastozoología Neotropical 20, 373-79.

Cione, A. L., Gasparini, G. M., Soibelzon, E., Soibelzon, L. H. \& Tonni, E. P. 2015. The Great American Biotic Interchange: A South American Perspective. In Rabassa, J., Lohman, G., Notholt, J., Mysak, L. A. \& Unnithan, V. (eds) SpringerBriefs in Earth System Sciences: South America and the Southern Hemisphere. Dordrecht, Heidelberg, New York, London: Springer. 98 pp.

Coues, E. 1887. Bassariscus, a new generic name in mammalogy. Science 9, 516

Croft, D. A. \& Anderson, L. C. 2008. Locomotion in the extinct notoungulate Protypotherium. Palaeontologia Electronica 11, 20.

Davis, D. D. 1964. The Giant Panda: a morphological study of evolutionary mechanisms. Fieldiana Zoology Memoirs 3. Chicago, IL: Chicago Natural History Museum. 368 pp.

Donadio, E., Di Martino, S., Aubone, M. \& Novaro, A. J. 2004. Feeding ecology of the Andean hog-nosed skunk (Conepatus ching $a$ ) in areas under different land use in northwestern Patagonia. Journal of Arid Environments 56, 709-18.
Elissamburu, A. \& Vizcaíno, S. F. 2004. Limb proportions and adaptations in caviomorph rodents (Rodentia: Caviomorpha). Journal of Zoology 262,145-59.

Ercoli, M. D., Prevosti, F. J. \& Álvarez, A. 2012. Form and function within a phylogenetic framework: locomotory habits of extant predators and some Miocene Sparassodonta (Metatheria). Zoological Journal of the Linnean Society 165, 224-51.

Ercoli, M. D., Álvarez, A., Stefanini, M. I., Busker, F. \& Morales, M. 2014. Muscular Anatomy of the forelimbs of the lesser grison (Galictis cuja), and a functional and phylogenetic overview of Mustelidae and other Caniformia. Journal of Mammal Evolution 22, 57-91.

Erra, G., Osterrieth, M. L., Morel, E. M. \& Fernández Honaine, M. 2010. Silicofitolitos de sedimentitas asociadas a "escorias y/o tierras cocidas", de la Formación Chapadmalal (Plioceno tardío temprano), de la provincia de Buenos Aires. In Ballent, S., Artabe, A. \& Tortello, F. (eds) X Congreso Argentino de Paleontología y Bioestratigrafía, VII Congreso Latinoamericano de Paleontología, Abstracts 106. $238 \mathrm{pp}$.

Evans, H. E. \& De Lahunta, A. 2013. Miller's Anatomy of the Dog. Elsevier Health Sciences.

Ewer, R. F. 1973. The carnivores. New York: Cornell University Press. 494 pp.

Fabre, A. C., Cornette, R., Slater, G., Argot, C., Peigné, S., Goswami, A. \& Pouydebat, E. 2013. Getting a grip on the evolution of grasping in musteloid carnivorans: a three-dimensional analysis of forelimb shape. Journal of Evolutionary Biology 26, 1521-35.

Fabre, A. C., Goswami, A., Peigné, S. \& Cornette, R. 2014. Morphological integration in the forelimb of musteloid carnivorans. Journal of Anatomy 225, 19-30.

Fabre, A. C., Salesa, M. J., Cornette, R., Antón, M., Morales, J. \& Peigné, S. 2015. Quantitative inferences on the locomotor behaviour of extinct species applied to Simocyon batalleri (Ailuridae, Late Miocene, Spain). The Science of Nature 102, 1-13.

Fleagle, J. G. 1998. Primate Adaptation and Evolution: 2nd Ed. London: Academic Press. 596 pp.

Forasiepi, A. M., Soibelzon, L. H., Gomez, C. S., Sánchez, R., Quiroz, L. I., Jaramillo, C., \& Sánchez-Villagra, M. R. 2014. Carnivorans at the Great American Biotic Interchange: new discoveries from the northern neotropics. Naturwissenschaften, 101, 965-74.

Fulton, T. L. \& Strobeck, C. 2007. Novel phylogeny of the raccoon family (Procyonidae: Carnivora) based on nuclear and mitochondrial DNA evidence. Molecular Phylogenetics and Evolution 43, $1171-77$.

Geoffroy Saint-Hilaire, E. \& Cuvier, F. G. 1795. Mémoire sur une nouvelle division des mammifères, et les principes qui doivent servir de base dans cette sorte de travail, lu à la Société d'Histoire naturelle, le premier floréal de I'an troisième. Magasin Encyclopédique 2, 164-87.

Glaston, A. R. 1994. The Red Panda, Olingos, Coatis, Raccoons, and their Relatives. UICN Status Survey and Conservation Action Plan for Procyonids and Ailurids. Gland, Switzerland: UICN. $103 \mathrm{pp}$.

Gompper, M. E. 1995. Nasua narica. Mammalian Species 487, 1-10.

Gompper, M. E. \& Decker, D. M. 1998. Nasua nasua. Mammalian Species 580, 1-9.

Gonyea, W. J. 1978. Functional implications of felid forelimb anatomy. Cells Tissues Organs 102, 111-21.

Grzimek, B., Schlager, N., Olendorf, D. \& McDade, M. C. 2004. Grzimek's Animal Life Encyclopedia. Farmington Hills, Michigan: Gale.

Hammer, Ø., Harper, D. A. T. \& Ryan, P. D. 2001. PAST-Paleontological statistics software package for education and data analysis. Palaeontologia electronica 4.9 pp.

Helgen, K. M., Pinto, C. M., Kays, R., Helgen, L. E., Tsuchiya, M. T., Quinn, A. \& Wilson, D. E. 2013. Taxonomic revision of the olingos (Bassaricyon), with description of a new species, the Olinguito. ZooKeys 324, 1-83. doi: 10.3897/zookeys.324.5827.

Hildebrand, M 1988. Analysis of Vertebrate Structure. New York: John Wiley \& Sons.

Hollister, N. 1915. The genera and subgenera of raccoons and their allies. Proceedings of the United States National Museum 49, $143-50$.

Iwaniuk, A. N., Pellis, S. M. \& Whishaw, I. Q. 1999. The relationship between forelimb morphology and behaviour in North American carnivores (Carnivora). Canadian Journal of Zoology 77, 106474.

Jones, K. E., Bielby, J., Cardillo, M., Fritz, S. F., O’Dell, J., Orme, C. D. L., Safi, K., Sechrest, W., Boakes, E. H., Carbone, C., Connolly, C., Cutts, M. J., Foster, J. K., Grenyer, R., Habib, 
M, Plaster, C. A., Price, S. A., Rigby, E. A., Rist, J., Teacher, A., Bininda-Emonds, O. R. P., Gittleman, J. L., Mace, G. M. \& Purvis A. 2009. PanTHERIA: a species-level database of life history, ecology, and geography of extant and recently extinct mammals. Ecology 90, 2648.

Junior, P. D. S., Dos Santos, L. M., Nogueira, D. M., Abidu-Figueiredo, M. \& Santos, A. L. 2015. Occurrence and morphometrics of the brachioradialis muscle in wild carnivorans (Carnivora: Caniformia, Feliformia). Zoologia (Curitiba) 32, 23-32.

Kasper, C. B., Soares, J. B., \& Freitas, T. R. 2012. Differential patterns of home-range, net displacement and resting sites use of Conepatus chinga in southern Brazil. Mammalian Biology-Zeitschrift für Säugetierkunde 77, 358-62.

Kraglievich, J. L. \& Reig, O. A. 1954. Un nuevo prociónido del Plioceno de las Playas (Provincia de Córdoba). Revista de la Asociación Geológica Argentina 9, 210-31.

Linares, O. J. 1981. Tres nuevos carnívoros prociónidos fósiles del Mioceno de Note y Sudamérica. Ameghiniana 18, 113-21.

Lynch, E. R. 2012. Cursorial Adaptations in the Forelimb of the Giant Short-Faced Bear, Arctodus simus, Revealed by Traditional and $3 D$ Landmark Morphometrics. Electronic Theses and Dissertations, East Tennessee State University, Paper 1477.

Martín-Serra, A., Figueirido, B. \& Palmqvist, P. 2014. A three-dimensional analysis of morphological evolution and locomotor performance of the carnivoran forelimb. PloSOne 9, e85574.

McClearn, D. 1992. Locomotion, posture, and feeding behaviour of kinkajous, coatis and raccoons. Journal of Mammalogy 73, 24561.

Moreno, F. P. \& Mercerat, A. 1891. Exploración arqueológica de la Provincia de Catamarca. Revista del Museo de La Plata, Paleontología $1,222-36$.

Mosimann, J. E. \& James, F. C. 1979. New statistical methods for allometry with application to Florida red-winged blackbirds. Evolution 33(1), 444-59.

Nowak, R. M. 2005. Walker's Carnivores of the World, 7th ed Baltimore: Johns Hopkins University Press. 328 pp.

O’Dea, A., Lessios, H. A., Coates, A. G.; Eytan, R. I., RestrepoMoreno, S. A., Cione, A. L., Collins, L. S., de Queiroz, A., Farris, D. W., Norris, R. D., Stallard, R. F., Woodburne, M. O., MariePierre Aubry, O. A., Berggren, W. A., Budd, A. F., Cozzuol, M. A., Coppard, S. E., Duque-Caro, H., Finnegan, S., Gasparini, G. M., Grossman, E. L., Johnson, K. G., Keigwin, L. D., Knowlton, N., Leigh, E. G., Leonard-Pingel, J. S., Marko, P. B., Pyenson, N. D., Rachello-Dolmen, P. G., Soibelzon, E., Soibelzon, L. H., Todd, J. A., Vermeij, G. J. \& Jackson, J. B. C. 2016. Formation of the Isthmus of Panama. Science Advances 2, e1600883.

Poglayen-Neuwall, I. \& Toweill, D. E. 1988. Bassariscus astutus. Mammalian Species Archive 327, 1-8.

Rovereto, C. 1914. Los estratos araucanos y sus fósiles. Anales del Museo Nacional de Historia Natural de Buenos Aires 25, 1-247.

Presley, S. J. 2000. Eira barbara. Mammalian Species 636, 1-6.

Salesa, M. J., Siliceo, G., Antón, M., Abella Pérez, J., Montoya Bello, P. \& Morales, J. 2006. Anatomy of the "false thumb" of Tremarctos ornatus (Carnivora, Ursidae, Tremarctinae): phylogenetic and functional implications. Estudios Geológicos $\mathbf{6 2}$

Samuels, J. X., Meachen, J. M. \& Stacey, A. S. 2013. Postcranial morphology and the locomotor habits of living and extinct carnivorans. Journal of Morphology 274, 121-46.

Sargis, E. J. 2002. Functional morphology of the forelimb of tupaiids (Mammalia, Scandentia) and its phylogenetic implications. Journal of Morphology 253, 10-42.

Schutz, H. \& Guralnick, R. P. 2007. Postcranial element shape and function: assessing locomotor mode in extant and extinct mustelid carnivorans. Zoological Journal of the Linnean Society 150, 895914.

Soibelzon, L. H. 2011. First description of milk teeth of fossil South American procyonid from the lower Chapadmalalan (Late Miocene-Early Pliocene) of "Farola Monte Hermoso", Argentina: paleoecological considerations. Paläontologische Zeitschrift $\mathbf{8 5}, 83-89$.
Soibelzon, L. H. \& Prevosti, F. 2007. Los carnívoros (Carnivora, mammalia) terrestres del Cuaternario de América del Sur. In Pons, G. X. \& Vicens, D. (eds) Geomorphologia Litoral i Quaternari. Homentage a D. Joan Cuerda Barceló. Monografies de la Societat d'Historia Natural de les Balears, Palma de Mallorca $\mathbf{1 4}$ 49-68.

Soibelzon, L. H. \& Prevosti, F. 2012. Fossils of South American Land Carnivores (Carnivora, Mammalia). In Ruiz-garcia, M. \& Shostell, J. M. (eds) Molecular Population Genetics, Evolutionary Biology and Biological Conservation of Neotropical Carnivores, 509-30. New York: Nova Science Publishers Inc. 720 pp.

Stalheim-Smith, A. 1984. Comparative study of the forelimbs of the semifossorial prairie dog, Cynomys gunnisoni, and the scansorial fox squirrel, Sciurus niger. Journal of Morphology 180, 55-68.

Storr, G. C. C. 1780. Prodromus methodi mammalium. Litteris Reissimis. Tubingae. $43 \mathrm{pp}$.

Tarquini, J., Soibelzon, L. H. \& Toledo, N. 2012. Anatomía de miembro anterior de Cyonasua sp. Ameghino (Carnivora, Procyonidae) del Plioceno Tardío de Miramar, Provincia de Buenos Aires. Ameghiniana 49, Supl. Resúmenes.

Tarquini, J., Morgan, C. C., Soibelzon L. H. \& Toledo N. 2015. Estimación del tamaño corporal de los prociónidos (Mammalia, Carnivora) fósiles del "grupo Cyonasua". Reunión de Comunicaciones de la Asociación Paleontológica Argentina. Libro de Resúmenes RCAPA, 23-24.

Taylor, M. E. 1974. The functional anatomy of the forelimb of some African Viverridae (Carnivora). Journal of Morphology 143, $307-$ 35.

Taylor, M. E. 1989 Locomotor adaptations by carnivores. In Gittleman, J. L. (ed.) Carnivore Behaviour, Ecology, and Evolution, 382-409. Ithaca, NY: Cornell University Press. $620 \mathrm{pp}$.

Toledo, N., Bargo, M. S., Cassini G. H. \& Vizcaíno S. F. 2012. The Forelimb of Early Miocene Sloths (Mammalia, Xenarthra, Folivora): Morphometrics and Functional Implications for Substrate Preferences. Journal of Mammalian Evolution 19, 185-98.

Toledo, N., Bargo, M. S. \& Vizcaíno, S. F. 2013. Muscular reconstruction and functional morphology of the forelimb of early Miocene sloths (Xenarthra, Folivora) of Patagonia. The Anatomical Record 296, 305-25.

Trapp, G. R. 1972. Some anatomical and behavioural adaptations of ringtails, Bassariscus astutus. Journal of Mammalogy 53, 549-57.

Van Valkenburgh, B. 1985. Locomotor diversity in past and present guilds of large predatory mammals. Paleobiology 11, 406-28.

Van Valkenburgh, B. 1987. Skeletal indicators of locomotor behaviour in living and extinct carnivores. Journal of Vertebrate Paleontology 7, 162-82.

Vizcaíno, S. F., Fariña, R. A. \& Mazzetta, G. V. 1999. Ulnar dimensions and fossoriality in armadillos. Acta Theriologica 44, 30920.

Vizcaíno, S. F. \& Milne, N. 2002. Structure and function in armadillo limbs (Mammalia: Xenarthra: Dasypodidae). Journal of Zoology 257, $117-27$

White, J. L. 1997. Locomotor adaptations in Miocene xenarthrans. In Kay, R. F., Madden, R. H., Cifelli, R. L., \& Flynn, J. J. (eds) Vertebrate Paleontology in the Neotropics: The Miocene Fauna of La Venta, Colombia, 246-64. Washington, DC: Smithsonian Institution Scholarly Press. 608 pp.

Wickham, H. 2009. ggplot2: Elegant Graphics for Data Analysis. New York: Springer-Verlag.

Wilson, D. E. \& Mittermeier, R. A. 2009. Handbook of the Mammals of the World.Vol.1: Carnivora. Barcelona, Spain: Lynx Edicions. $728 \mathrm{pp}$.

Woodburne, M. A., Cione, A. L. \& Tonni, E. P. 2006. Central American Provincialism and the Great American Biotic Interchange. In Carranza-Castañeda, O. \& Lindsay, E. H. (eds) Advances in late Tertiary vertebrate paleontology in Mexico and the Great American Biotic Interchange. Publicación Especial del Instituto de Geología y Centro de Geociencias de la Universidad Nacional Autónoma de México 4, 73-101.

Yensen, E. \& Tarifa, T. 2003. Galictis vittata. Mammalian Species $727,1-8$

MS received 22 May 2015. Accepted for publication 26 August 2016. 
